\title{
Naskah Pidato Kenegaraan Presiden Joko Widodo dalam Perspektif Komunikasi Politik dan Pembangunan
}

\author{
Rini Riyantini dan Sarwititi \\ Program Studi Ilmu Komunikasi UPN Veteran Jakarta \\ Dosen Komunikasi Pembangunan dan Pertanian Pedesaan \\ Email:
}

\begin{abstract}
This study aims to analyze the comparison between State Speech Text of President Joko Widodo Year 2016 and 2017 based on the perspective of political communication and communication development. The method used is a critical discourse with document studies in the form of a state speech text of 2016 and 2017. The Text is analyzed using dimensions of microstructure, mesostructure and macrostructure of Norman Fair-clogh model. The results of the analysis show that the text of the state speech of 2017 is more nuanced political communication both in microstructure, mesostruktur and macrostructure with the dominant use of symbols of political language related to the current political situation.
\end{abstract}

Keywords: State Speech Text, Political Communication, Development Communication

\begin{abstract}
Abstrak
Penelitian in bertujuan menganalisis perbandingan antara Naskah Pidato Kenegaraan Presiden Joko Widodo Tahun 2016 dengn tahun 2017 berdasarkan perspektif komunikasi politik dan komunikasi pembangunan. Metode yang digunakan adalah wacana kritis dengan studi dokumen berupa naskah pidato kenegaraan tahun 2016 dan tahun 2017. Naskah dianalisis menggunakan dimensi mikrostruktur, mesostruktur dan makrostruktur model Norman Fair-clogh. Hasil analisis menunjukkan bahwa naskah pidato kenegaraan tahun 2017 lebih bernuansa komunikasi politik baik secara mikristruktur, mesostruktur maupun makrostruktur dengan dominasi penggunaan simbol bahasa politik yang berkaitan dengan situasi politik saat itu.
\end{abstract}

Kata Kunci: Naskah Pidato Kenegaraan, Komunikasi politik, Komunikasi Pembangunan

\section{Pendahuluan}

Gaya komunikasi yang terkesan tidak formal, sederhana dan ceplas ceplos dari presiden Joko Widodo sejak masa kampanye pilihan presiden sampai saat ini seolah melekat dan menjadi karakter tersendiri. Bahkan tidak jarang juga mengundang kontroversi opini dan komentar beberapa pengamat politik sehingga menjadi fenomena tersendiri terutama dalam menyelesaikan beberapa persoalan hubungan antar tokoh, juga dengan lawan politiknya. Sebagai seorang presiden tentu menjadi sorotan utama seluruh tokoh serta pengamat politik di negeri ini bahkan secara internasional, sehingga menjadi salah satu fenomena yang menarik dari gaya komunikasi untuk diteliti, sehingga banyak hasil penelitian yang terkait dengan gaya komunikasi telah dilakukan.

$$
\text { Asmara (2016) mengkaji aspek }
$$

Kebahasaan Presiden Jokowi Dalam 
Menanamkan Ideologi Dan Manifesto Pemerintahan, Ayuningtyas dan Sari (2014) meneliti terkait dengan Pidato Politik Di Indonesia: Sebuah Kajian Wacana Kritis. Sebagai Kepala Negara dan Kepala Pemerintahan, Presiden merupakan komunikator tertinggi bagi seluruh rakyatnya, sehingga pesan secara verbal dan non verbal menjadi perhatian yang akan dipersepsi sebagai sebuah kebenaran oleh komunikan. Komunikasi yang dilakukan sebagai seorang Kepala Negara dan Kepala pemerintahan yang merupakan kewajiban dan dianggap sebagai konvensi adalah pidato kenegaraan yang disampaikan oleh Presiden di hadapan sidang Majelis Permusyawaratan Rakyat setiap tanggal 16 Agustus.

Nurfadillah (2017) meneliti aspek markah dan tulis dari persektif makna konotasi dengan hasil hanya terdapat 7 kata dan prase yang bermakna konotatif dari pidato perdana Presiden Joko Widodo. Sedangkan Ricky (2014) menganalisis perbandingan retorika Aristoteles antara Prabowo dan Joko Widodo ditinjau dari perspektif ethos, pathos, logos, dengan hasil perbandingan Joko Widodo lebih logis dalam retorikanya dibandingkan Prabowo. Sementara Khalid dan Affandy (2015) meneliti hegemoni berdasarkan tiga dimensi dengan hasil bahwa pada dimensi tekstual (mikrostruktural), banyak digunakan diksi dan konjungsi, pada dimensi kewacanaan (mesostruktural), diketahui bahwa majalah Tempo tidak terafiliasi dengan pemerintah, pada dimensi praktis sosial budaya (makrostruktural), diketahui terdapat isu politik pada majalah Tempo.

Wacana kritis yang dilakukan Humaidi (2017) terhadap pidato Susilo Bambang Yudhoyono menggunakan model Teun A. Van Dijk, Munfarida (2014) mengkaji literatur wacana kritis Nourman Ferclocgh, Sidharta (2017) meneliti terkait strategi i m p r e s s i o $n$ managemen yang terkait dengan program isu pemerintah melalui youtube dengan hasil bahwa strategi ini secara dominan ditunjukkan melalui indikator mengucapkan salam, terima kasih, serta menyatakan pernyataan yang bersifat humor.
Penelitian ini merupakan wacana kritis perbandingan pidato kenegaraan Presiden Joko Widodo tanggal 16 Agustus 2016 dan tanggal 16 Agustus 2017 berdasarkan perspektif komunikasi politik dan komunikasi pembangunan, dengan menggunakan model Norman Ferclogh yang menjelaskan pertanyaan penelitian apakah aspek teks, produsi dan komsumsi teks serta sosiokultural pada naskah pidato tahun 2016 berbeda dengan naskah pidato tahun 2017 ?

Nimmo (2000:8) mengartikan politik sebagai kegiatan orang secara kolektif yang mengatur perbuatan mereka di dalam kondisi konflik sosial. Dalam berbagai hal orang berbeda satu sama lain - jasmani, bakat, emosi, kebutuhan, cita-cita, inisiatif, perilaku, dan sebagainya. Lebih lanjut Nimmo menjelaskan, kadang-kadang perbedaan ini merangsang argumen, perselisihan, dan percekcokan. Jika mereka menganggap perselisihan itu serius, perhatian mereka dengan memperkenalkan masalah yang bertentangan itu, dan selesaikan; inilah kegiatan politik.

Sementara komunikasi politik adalah komunikasi yang diarahkan kepada pencapaian suatu pengaruh sedemikian rupa, sehingga masalah yang dibahas oleh jenis kegiatan komunikasi ini, dapat mengikat semua warganya melalui suatu sanksi yang ditentukan bersama olehlembaga-lembaga politik(Soesanto, 1980:2). Sedangkan Lasswell (dalam Varma, 1995:258) memandang orientasi komunikasi politik telah menjadikan dua hal sangat jelas: pertama, bahwa komunikasi politik selalu berorientasi pada nilai atau berusaha mencapai tujuan; nilai-nilai dan tujuan itu sendiri dibentuk di dalam dan oleh proses perilaku yang sesungguhnya merupakan suatu bagian; dan kedua, bahwa komunikai politik bertujuan menjangkau masa depan dan bersifat mengantisipasi serta berhubungan dengan masa lampau dan senantiasa memperhatikan kejadian masa lalu.

Pramono (2016) menyatakan bahwa dalam pendekatan partisipatoris, semua permasalahan yang dihadapi merupakan masalah bersama sehingga cara menyelesaikannya pun 
perlu dipikirkan bersama. Karena aktivitas komunikasi terjadi dalam ruang publik (public sphere) maka memungkinkan setiap orang dapat melakukan akses informasi dan dialog terbuka secara merata. Lebih lanjut disampaikan Selain itu, pendekatan partisipatoris memfokuskan pada penggalian dan pemanfaatan potensi media lokal (indigenous media) sebagai alternatif pengguanaan media komunikasi modern bagi tumbuhnya partisipasi warga masyarakat setempat. Dengan demikian, pendekatan partisipatoris sebagai strategi komunikasi pembangunan mengutamakan arus komunikasi yang berlangsung dua arah sebagai ciri komunikasi sosial dengan penggabungan model analisis isi media dan model yang berorientasi kepada khalayak. Proses ini memberi peran dan tanggung jawab bersama kepada semua pihak yang terlibat komunikasi dalam pendistrubsian informasi secara merata dalam praktik komunikasi pembangunan. Berdasarkan model pendekatan partisipatoris, usaha pembangunan yang berpusat pada rakyat dengan inisiatif dan kreativitas, dan swadaya individu dan kelembagaan dalam masyarakat seperti yang diungkapkan Korten dan Carner dalam Pramono (2016) dapat diwujudkan.

\section{Metode Penelitian}

Pendekatan yang digunakan dalam penelitian ini adalah kualitatif wacana naskah pidato kenegaraan Presiden Joko Widodo tanggal 16 agustus Tahun 2016 dan 2917 dengan model analisis yang Norman Ferlocght. Fairclough dalam Eryanto (2006) berpendapat bahwa analisis wacana kritis adalah bagaimana bahasa menyebabkan kelompok sosial yang ada bertarung dan mengajukan ideologinya masingmasing. Analisis Wacana melihat pemakaian bahasa tutur dan tulisan sebagai praktik sosial. Praktik sosial dalam analisis wacana dipandang menyebabkan hubungan yang saling berkaitan antara peristiwa yang bersifat melepaskan diri dari dari sebuah realitas, dan struktur sosial. Kajian sebelumnya dilakukan oleh Jupriono dkk (2009) ini berada dalam ruang lingkup wacana (discourse), yang berfokus pada elemen semantis wacana, dari perspektif analisis wacana kritis (critical discourse analysis) versi van Dijk.

Arifin mengutip Fairclough dalam Jorgensen dan Phillips, 2007: 135 menyatakan analisis wacana kritis sebagai pendekatan upaya penyelidikan secara sistematis terhadap hubungan-hubungan kausalitas praktik kewacanaan, peristiwa dan teks, serta strukturstruktur kultural dan sosial yang lebih luas. Objek penelitian berupa 2 (dua) naskah pidato, yang tediri atas 3 bagian yaitu bagian pembuka, bagian isi, dan bagian penutup untuk dilakukan studi dokumen dengan unit analisis bagian serta paragraf yang terdapat keterkaitan dengan dimensi analisis. Teknik analisis wacana kritis Norman Fairlcough yang meliputi teks, produksi dan penerimaan teks serta dimensi kognisi sosial. Teknik analisis wacana kritis dilakukan dengan Model Norman Fairclough (Eriyanto, 2001: 286) membagi analisis wacana kritis ke dalam tiga dimensi, yaitu dimensi tekstual (mikrosruktural) yang terdiri atas kohesi dan koherensi, tata bahasa, dan diksi. Dimensi Kewacanaan (Mesostruktural) proses produksi, penyebaran, dan penggunaan teks. Serta dimensi adalah analisis praktik sosiobudaya (makrostruktural) yang meliputi situasional, institusional dan sosial.

\section{Hasil dan Pembahasan}

Hasil penelitian terhadap naskah pidato kenegaraan Presiden Joko Widodo dapat dianalisis berdasarkan Fair-clought sebagai berikut :

Naskah dan unit analisis

\begin{tabular}{|c|c|c|c|}
\hline \multirow{2}{*}{ Tahun Naskah } & \multicolumn{3}{|c|}{ Struktur Naskah/Paragraf } \\
\cline { 2 - 4 } & Pembuka & Isi & Penutup \\
\hline Tahun 2016 & 3 paragraf & 52 paragraf & 2 paragraf \\
\hline Tahun 2017 & 4 paragraf & 31 paragraf & 2 paragraf \\
\hline
\end{tabular}




\section{Dimensi Mikrostruktur}

\begin{tabular}{|c|c|c|}
\hline Mikrostruktur & Naskah Tahun 2016 & Naskah Tahun 2017 \\
\hline $\begin{array}{l}\text { Kohesi dan } \\
\text { Koherensi }\end{array}$ & $\begin{array}{l}\text { Isi: Terdapat } 13 \text { paragraf yang } \\
\text { terkait dengan komunikasi politik } \\
\text { dan } 39 \text { paragraf mengandung maksa } \\
\text { pembangunan, dengan penggunaan kata- } \\
\text { kata yang diulang terhadap penekanan } \\
\text { aspek prioritas, kesinambungan antar } \\
\text { paragraf bisa, sehingga dapat dirasakan } \\
\text { semakin tenang } \\
\text { Penutup: Bersifat pemberi semangat, } \\
\text { mengajak seluruh rakyat untuk } \\
\text { bertanggungjawab dan berpatrisipasi. } \\
\text { Lebih bersifat memotivasi secara tegas. }\end{array}$ & $\begin{array}{l}\text { Pembuka: Terdapat pengulangan } \\
\text { kata sapa, tetapi yang disapa terlebih } \\
\text { dahulu adalah rakyat Indonesia } \\
\text { dengan menyebutkan batas wilayah } \\
\text { paling timur dan paling barat, baru } \\
\text { para pejabat negara, serta lebih } \\
\text { agamis. } \\
\text { Isi: Terdapat } 17 \text { paragraf dari } 31 \\
\text { paragraf yang bernuansa komunikasi } \\
\text { politik dan } 14 \text { paragraf berbicara } \\
\text { capaian program pembangunan. }\end{array}$ \\
\hline Tata Bahasa & $\begin{array}{l}\text { Pembuka: } \\
\text { Penggunaan kata sapa kepada lembaga } \\
\text { pemerintah serta pejabat } \\
\text { Isi: } \\
\text { Penggunaan kata serta kalimat yang } \\
\text { lugas, sederhana, tidak banyak } \\
\text { bermain data keberhasilan, lebih } \\
\text { banyak penekanan terhadap program } \\
\text { pembangunan serta SDM yang persuasif }\end{array}$ & $\begin{array}{l}\text { Pembuka: } \\
\text { Penggunaan kata sapa yang } \\
\text { berorientasi kepentingan rakyat } \\
\text { Indonesia dari Sabang sampai } \\
\text { Merouke. } \\
\text { Isi: } \\
\text { Lebih banyak mengungkapkan data } \\
\text { keberhasilan pembangunan serta } \\
\text { dengan penggunaan kalimat aktif } \\
\text { menunjukkan sebagai pekerja pelaku } \\
\text { pembagunan, namun mengkritisi } \\
\text { mental serta konflik antar golongan } \\
\text { Penutup: } \\
\text { Lebih banyak mendorong untuk } \\
\text { bersemangat kerja keras dan } \\
\text { bersinergi }\end{array}$ \\
\hline
\end{tabular}




\begin{tabular}{|c|c|c|}
\hline & 2 & 3 \\
\hline Diksi & $\begin{array}{l}\text { Pembuka: } \\
\text { Ditujukan kepada lembaga pemerintahan } \\
\text { dan pimpinan lembaga tersebih dahulu, } \\
\text { kemudian seluruh bangsa Indonesia } \\
\text { Isi: } \\
\text { Perumusan naskah pidato ini terlihat } \\
\text { sesuai karakter presiden Jokowi yang } \\
\text { selalu berbicara apa adanya, hanya } \\
\text { dikemas dalam bahasa yang formal oleh } \\
\text { tim perumus kepresidenan } \\
\text { Penutup: } \\
\text { Penegasan untuk menjadi bangsa } \\
\text { Indonesia yang kuat yang mampu } \\
\text { bersaing }\end{array}$ & $\begin{array}{l}\text { Pembuka: } \\
\text { Ditujukan kepada seluruh rakyat } \\
\text { dengan penegasan wilayah Indonesia } \\
\text { Isi: } \\
\text { Penguatan lembaga pemerintah } \\
\text { sebagai pelayan, serta prestasi } \\
\text { masing-masing kelembagaan } \\
\text { Penutup: } \\
\text { Mencerminkan semangat persatuan } \\
\text { terutama untuk seluruh lembaga } \\
\text { pemerintah untuk terus bekerja } \\
\text { bersama untuk rakyat }\end{array}$ \\
\hline
\end{tabular}

\section{Dimensi Kewacanaan}

Pada dimensi kewacanaan (discourse practice) analisis wacana kritis Norman Fairclough merupakan penafsiran yang dilakukan terhadap pemrosesan wacana yang meliputi aspek penghasilan, penyebaran, dan penggunaan teks. Dalam merumuskan pidato kenegaraan Presiden, melalui proses pengumpulan data secara organisatoris Presiden bekerja dibantu oleh wakil Presiden dan Para menteri yang berada pada Kabinet Kerja , sehingga seluruh kementerian yang memberikan data-data kinerja di setiap bidang untuk dapat dihimpun oleh Tim Kepresidenan melalui Sekterariat Negara dalam menyiapkan naskah pidato yang merupakan pertanggungjawaban kinerja Presiden selaku Kepala Pemerintahan setiap tahun di hadapan MPR selama masa jabatan.

Dalam naskah pidato tahun 2016 merupakan tahun kedua kinerja Presiden sehingga lebih kepada ungkapan pondasi program, belum terlalu banyak capaian yang dapat diukur, sehingga lebih banyak berbicara tentang perubahan regulasi, aspek pelayanan publik serta proses mental seluruh manusia Indonesia untuk mengatasi tantangan. Kemudian aspek reformasi birokrasi terutama dalam efisiensi penggunaan harus berorientasi pada bebas korupsi dan produktif kerja, kritik para birokrat yang banyak dinas luar. Kemudian bicara peranserta diplomasi internasional serta hubungan luar negeri serta turut serta aktif berpartisipasi dalam penyelesaian konflik Internasional.

Tahap produksi teks pidato tahun 2016 selain keterlibatan tim perumus yang memiliki karakter serta kompetensi bidang komunikasi yang terkait dengan program pembangunan serta politik. Sosialisasi serta pelaksanaan program pembangunan yang banyak mengundang kontroversi dari lawan politiknya memberikan warna pada naskah pidato kenegaraan aspek politik dengan mengemukakan pergolakan politik yang berimbas dari luar, padahal di dalam sendiri juga bergolak, itulah nuansa naskah pidato tahun kedua yang banyak diwarnai oleg progres pembangunan SDM. Mental, serta infra struktur. Pembangunan ekonomi juga sangat tergantung pada fasilitas infra struktur bidang transportasi karena tidak terhubungnya daerah yang satu dengan daerah lainnya, maka perekonomian tidak akan tumbuh.

Tentu saja produksi teks pidato tidak lepas dengan proses negosiasi presiden, sehingg penggunaan kata, istilah maupun kalimat benarbenar sesuai dengan karakter Presiden Joko Widodo. Pengemasan naskah pidato kenegaraan pun mempertimbangkan aspek distribusinya ke selruh tanah air bahkan ke luar negeri melalui 
berbagai media, sehingga penggunaan bahasa harus dapat dipahami oleh seluruh masyarakat Indonesia, tidak hanya MPR sebagai lembaga tertinggi yang mengangkat dan memberhentikan presiden, tetapi juga sebagai representasi perwakilan rakyat Indonesia.

Perumusan pesan pun harus senantiasa mempertimbangkan siapa khalayak sasaran yang akan menerima naskah pidato kenegaraan tersebut, bukan hanya lembaga tertinggi maupun tinggi negara, tetapi juga seluruh rakyat Indonesia, sehingga pengemasan bahasa, simbol bahkan istilah

Harus disesuaikan dengan yang akan menerima pesan/naskah pidato itu.

Dianalisis pihak-pihak yang menjadi sasaran penerima/pengonsumsi teks. Perlu juga pada kasus wacana media perlu dilakukan analisis yang mendalam mengenai siapa saja pengonsumsi media itu sendiri. setiap media pada umumnya telah menentukan "pangsa pasar"nya masingmasing.

\section{Dimensi Praktis Sosial-Budaya}

Dimensi ketiga adalah analisis praktik sosiobudaya media dalam analisis wacana kritis Norman Fairclough merupakan analisis tingkat makro yang didasarkan pada pendapat bahwa konteks sosial yang ada di luar naskah sesungguhnya memengaruhi bagaimana wacana yang ada ada dalam teks. Ruang redaksi atau wartawan bukanlah bidang atau ruang kosong yang steril, tetapi juga sangat ditentukan oleh faktor-faktor di luar media itu sendiri. Praktik sosial-budaya menganalisis tiga hal yaitu ekonomi, politik (khususnya berkaitan dengan isu-isu kekuasaan dan ideologi) dan budaya (khususnya berkaitan dengan nilai dan identitas) yang juga mempengaruhi istitusi media, dan wacananya. Pembahasan praktik sosial budaya meliputi tiga tingkatan Tingkat situasional, berkaitan dengan produksi dan konteks situasinya Tingkat institusional, berkaitan dengan pengaruh institusi secara internal maupun eksternal. Tingkat sosial, berkaitan dengan situasi yang lebih makro, seperti sistem politik, sistem ekonomi, dan sistem budaya masyarakat secara keseluruhan.

Tiga level analisis sosiocultural practice ini meliputi aspek situasional, artinya teks lahir pada situasi tertentu yang akan berpengaruh terhadap situasi pembentukan teks itu sendiri. Setiap teks yang lahir pada umumnya lahir pada sebuah kondisi (lebih mengacu pada waktu) atau suasana khas dan unik. Atau dengan kata lain, aspek situasional lebih melihat konteks peristiwa yang terjadi saat berita dibuat. Dapat dibandingkan antara teks pidato yang tahun 2016 dan tahun 2017 disajikan dalam bentuk bahasa dan penekanan sasaran yang berbeda sesuai kebutuhan akan situasi saat itu. Level ini melihat bagaimana persisnya sebuah pengaruh dari institusi organisasi pemerintahan pada praktik ketika sebuah wacana diproduksi. Institusi ini bisa berasal dari kekuatan institusional aparat dan pemerintah juga bisa dijadikan salah satu hal yang mempengaruhi isi sebuah teks.

Begitu juga aspek sosial yang melihat lebih pada aspek mikro seperti sistem ekonomi, sistem politik, atau sistem budaya masyarakat keseluruhan. Dengan demikian, melalui analisis wacana model ini, kita dapat mengetahui inti sebuah teks dengan membongkar teks tersebut sampai ke hal-hal yang mendalam. Ternyata, sebuah teks pun mengandung ideologi tertentu yang dititipkan penulisnya agar masyarakat dapat mengikuti alur keinginan penulis teks tersebut.

Seperti yang dirilis Kompas.com 11 September 2017, Setiap kali kita menonton acara-acara talkshow politik, kita melihat para politikus bicaranya terlalu kasar. Mereka seakan tidak peduli pada personal brandingnya sendiri. Bukan cuma omongannya tapi juga tindakannya. Coba lihat acara Indonesia Lawyer Club, hampir semua narasumber berteriak-teriak menyerang lawannya sehingga memberikan enerji negatif pada yang penonton bahkan cenderung mengganggu kewarasan para pemirsa. Tetapi sangat berbeda dengan Presiden Joko Widodo, politisi yang paling santun, tidak pernah merespon isu-isu yang dilempar oleh lawan politiknya, kalaupun terpaksa cukur hanya 
tersenyum dengan memberikan simbol-simbol.

Seolah tidak berdaya dan rapuh setiap dikritisi tajam oleh lawan politiknya, Pesiden Joko Widodo senantiasa menggunakan caracara yang sangat halus untuk menepis lawan politiknua. Seperti waktu terdapat liputan di Televisi Jokowi pergi ke hambalang dan berkomentar terkait dana yang menyebabkan berbagai kasus korupsi dari lawan politiknya, merupakan simbol yang senantiasa diberikan oleg Presiden Joko Widodo. Bagi penonton mungkin tidak akan paham dan dianggap biasa dengan sikap Joko Wi, tetapi itulah interprtasi simbol yang menarik untuk dianalisis.

Begitu juga dengan teks yang terdapat dalam pidato kenegaraan, walaupun cukup santun tetapi terdapat penekanan-penekanan yang tegas terhadap aspek aspek yang terkait dengan komunikasi politiknya. Intinya adalah, setiap kali diserang, Jokowi memang selalu bereaksi terhadap sebuah serangan dengan cara yang halus dan elegan. Itulah yang selalu membuat saya tertarik. Dia menangkis semua serangan itu dengan simbol-simbol.Banyak orang yang malas berpikir dan berkomentar bahwa pidato Jokowi tidak ada isinya. Pendapat itu sah-sah aja karena pidato Jokowi memang dikemas seakan-akan disampaikan untuk rakyat tapi sebenernya dia tujukan untuk lawan politiknya.

Simbol-simbol seperti itulah yang membuat para pengamat politik tertarik untuk mendalami sebetulnya apa yang sedang dilakukan Jokowi. Pada teks pidato tahun 2017, disampaikan bahwa tidak ada 1 lembaga pemerintah pun yang memiliki kekuasaan absolut, ini terkait dengan situasi pada saat itu terkena isu bahwa pemerintahannya otoriter. Presiden Jokowi juga menyebut bahwa tantangan yang paling penting, dan menjadi prioritas semua lembaga negara, adalah mendapatkan kepercayaan tinggi dari rakyat. "Saya mengajak kita semua untuk bergandengan tangan, bekerja bersama, untuk mewujudkan keadilan sosial bagi seluruh rakyat Indonesia" ujar Jokowi. Di luar hal itu ada beberapa hal yang disebutkan oleh Presiden Jokowi. Simak beberapa hal berikut dan faktanya yang juga tercantum pada naskah pidato, yaitu Meningkatkan SDM dan memangkas ketimpangan.

Data yang ditampilkan pada teks pidatonya itu ternyata tidak jauh berbeda atau sesuai dengan kenyataan. Presiden Jokowi menyebutkan bahwa Indeks Pembangunan Manusia (IPM) naik dari 68,90 pada tahun 2014 menjadi 70,18 tahun 2014 - 2016. Rappler juga mencatat jiha ada pertumbuhan yang dirilis BPS sejak tahun 2010-2016. Kinerja parlemen pun sama, dispresiasi oleh presiden di dalam teks pidatonya yang mengungkankan bahwa "DPD telah menunjukan kematangannya, setelah melalui masa-masa sulit konsolidasi internalnya". Hingga pertengahan semester 2017, DPD telah mengerjakan 10 pertimbangan terhadap RUU, 5 pertimbangan berkaitan dengan anggaran, dan 13 hasil pengawasan terhadap pelaksanaan undang-undang tertentu.

Kemudian untuk memotivasi lembaga juga dalam pidatonya tidak hanya menyampaikan hasil kerja, tetapi juga terkait kebutuhan terhadap produk kerja dari seluruh kementerian/ lembaga terkait. Misalnya dalam pidatonya menyebut bahwa beberapa dari pertimbangan itu ada yang sangat diperlukan untuk mempercepat pemerataan pembangunan di daerah-daerah seperti Pertimbangan atas RUU tentang Pengelolaan Kawasan Perbatasan Negara, dan RUU tentang Kewirausahaan Nasional, serta Pengawasan atas pelaksanaan Undang-Undang tentang desa.

Beberapacapaian pembangunan/program juga sudah diapresiasi misalnya Apresiasi juga ditunjukan Presiden Jokowi terhadap dua badan hukum yakni, Mahkamah Agung dan Mahkamah Konstitusi. Selain memperluas layanannya kepada masyarakat di daerah terpencil melalui program "Sidang Keliling", Mahkamah Agung (MA) juga melanjutkan akreditasi untuk menjamin mutu badan peradilan. "Hingga bulan Juni 2017, telah berhasil mengakreditasi 186 pengadilan" ujar Jokowi. MK juga ementara Mahkamah Konstitusi (MK) meraih Bawaslu Award, karena telah menyelesaikan seluruh 
perkara hingga pertengahan tahun 2017 yang berjumlah 55 perkara.

Selain MAdan MK, KomisiYudisial(KY), juga memperoleh pujian dari Presiden karena telah memajukan akuntabilitas peradilan di tanah air. Komisi Yudisial telah menyelesaikan 8 kasus advokasi hakim, serta melakukan pemantauan 89 persidangan atas laporan masyarakat. KY juga disebut telah melakukan penyelenggaraan pelatihan kode etik dan pedoman perilaku bagi 277 hakim. Dalam menjaga martabat peradilan, KY juga telah merekomendasikan penjatuhan sanksi bagi 33 hakim, mulai dari sanksi ringan hingga berat.

Memerangi kemiskinan, memeratakan pembangunan, dan perbaikan ekonomi, untuk ini selama tiga tahun pemerintahan Jokowi, pemerintah telah berhasil menekan angka kemiskinan dari 28,59 juta orang pada Maret 2015 menjadi 27,77 juta pada Maret 2017, serta banyak lagi data yang diungkap dalam naskah pidato Kenegaraan tersebut.

\section{Simpulan}

Terdapat perbedaan perbedaan penyajian naskah antara pidato Kenegaraan Presiden Joko Widodo antara Tahun 2016 dan 2017, naskah pidato tahun 2017 lebih banyak bernuansa komunikasi politik dari pada pembangunan dibandingkan dengan tahun 2016

Secara mikrosruktur naskah pidato keduanya tertata secara kohesi dan koheren, tata bahasa serta diksi yang berhubungan antar paragraf dalam teks pidato terbut. Berdasarkan mesostruktur, karakteristik komunikasi politik terlihat menonjol terutama dalam penggunaan simbol-simbol dalam teks yang terkait dengan kritikal terhadap khalayak sasaran

Secara makrostruktural teks pidato kenegaraan Presiden Joko Widodo lebih dominan situasi politik saatteks dibuat, sehingga tahun 2016 lebih bernuansa pada program program pembangunan, sedangkan pada tahun 2017 nuansa politiknya lebih menonjol walaupun didukung dengan sajian data keberhasilan pembangunan.

\section{Daftar Pustaka}

Arifin E. Zaenal, Perkembangan Teori Dan Teknik Analisis Wacana: Dari Teori Konvensional Ke Teori Modern, Jurnal Pujangga Volume 3, Nomor 1, Juni 2017

Asmara Rangga, Strategi Kebahasaan Presiden Jokowi Dalam Menanamkan Ideologi Dan Manifesto Pemerintahan , Litera, Volume 15, Nomor 2, Oktober 2016, hal: 379-389. Ayuningtias Diah Ikawati dan Sari Erika Citra Hartanto, Pidato Politik Di Indonesia: Sebuah $\quad K$ a j i a $n$ Wacana Kritis , Prosodi, Volume VIII nomor 1 Januari 2014, hal:25-38 Badara, Aris. 2012. Analisis Wacana: Teori, Metode, dan Penerapannya pada Wacana Media. Jakarta: Kencana Prenada Media Group. Eriyanto. 2006. Analisis Wacana: Pengantar Analisis Teks Media. Yogyakarta: LKIS. Hamad, Ibnu, Lebih Dekat dengan Analisis Wacana, 325-343, MediaTor volume 8 no 2, 2007.

Humaidi Akhmad, Struktur Teks, Kognisi Sosial, Dan Dimensi Sosial Pidato Susilo Bambang S S N : 2580 5932, http://ppjp.unlam.ac.id/journal/ index.php/jbsp/is sue/view/564 Jupriono D;Sudarwati; Rahayu,; Parafrase Vol. 09. No. 02 September 2009, hal: 5565, http://jurnal.untag-sby.ac.id/index. $\mathrm{php/parafrasa/article/view/110/61}$

Khalid Hasan Moh. dan Affandy Ali Nuke, Hegemoni KetuaPartaiTerhadapPresiden Dalam Majalah Tempo Edisi 13 - 19 April 2015 (Studi Analisis Wacana Kritis), Lingua Franca: Issn: 2580-3255 Vol.1 No. 2 Agustus 2017 Hal 36 - 41 Munfarida Elya, Analisis Wacana Kritis Dalam Perspektif Norman Fairclough, Komunika, Vol. 8, No. 1, Januari Juni 2014, ISSN: 1978 1261, hal: 1-21

Nimmo, Dan. 2000. Komunikasi Politik (Komunikator, Pesan, dan Media). Terjemahan: Tjun Surjaman.Cetakan 
III, Remadja Rosdakarya, Bandung. Nurpadillah Veni, Wacana Kepemimpinan: Analisis Makna Konotasi Dalam Teks Pidato Perdana Presiden Jokowi (Leadership Work: Consumer Meaning Analysis in Primary Property Text Principle Jokowi), Jalabahasa, Volume 13, Nomor 1 Tahun 2017 Prayogi Rahmat dan Eko Rusminto Nurlaksana, Wacana Berita Bertajuk Korupsi Dalam Situs Indonesiana Dan Implikasi Pembelajaran Analisis Wacana, J-Simbol (Bahasa, Sastra, dan Pembelajarannya) April 2016, Magister Pendidikan Bahasa dan Sastra Indonesia Hal: 1-6 Ricky Heru (2014) Perbandingan Retorika Prabowo Subianto Dan Joko Widodo Dalam Debat Calon Presiden 2014, (Studi Kasus Retorika Debat Calon
Presi den 2014 Mengenai Pembangunan Ekonomi dan Kesejahteraan Sosial), Jurnal Ilmu Komunikasi, http://ejournal.uajy.ac.id/6445/ p.1-13. SiedhartaIndira,IndrayaniInriInggrit,danMonica Vita, Strategi Impression Management Pramono, Pembangunan dan Media Massa:Suatu Telaah Historis, Paradigmatik dan Prospektif ETTISAL Journal of Communication, Vol.1, No.1, Juni 2016, Presiden Joko Widodo Melalui Komunikasi Program Prioritas Pemerintah Dalam Akun Youtube "Presiden Joko Widodo", doi: $\quad$ 10.9744/scriptura.7.1.17-26

Soesanto Astrid, S. 1980. Komunikasi Sosial di Indonesia. Bina Cipta, Jakarta. Varma, S.P. 1995. Teori Politik Modern, PT Raja Grafindo Persada, Jakarta. 